\title{
Abraham's reinterpretation and life's meaning
}

\begin{tabular}{|c|c|}
\hline $\begin{array}{l}\text { Author: } \\
\text { Jurie H. le Rou }\end{array}$ & \\
\hline $\begin{array}{l}\text { Affiliation: } \\
{ }^{1} \text { Department }\end{array}$ & of Old \\
\hline $\begin{array}{l}\text { Testament Stu } \\
\text { of Pretoria, So }\end{array}$ & $\begin{array}{l}\text { dies, University } \\
\text { uth Africa }\end{array}$ \\
\hline $\begin{array}{l}\text { Corresponden } \\
\text { Jurie le Roux }\end{array}$ & ce to: \\
\hline $\begin{array}{l}\text { Email: } \\
\text { jleroux1@mw }\end{array}$ & eb.co.za \\
\hline $\begin{array}{l}\text { Postal address } \\
9 \text { Elephant Ro } \\
\text { Park, Pretoria } \\
\text { South Africa }\end{array}$ & $\begin{array}{l}\text { s: } \\
\text { ad, Monument } \\
\text { 0181, }\end{array}$ \\
\hline $\begin{array}{l}\text { Dates: } \\
\text { Received: } 27 \\
\text { Accepted: } 11 \\
\text { Published: } 30\end{array}$ & $\begin{array}{l}\text { Mar. } 2015 \\
\text { Aug. } 2015 \\
\text { Nov. } 2015\end{array}$ \\
\hline $\begin{array}{l}\text { How to cite th } \\
\text { Le Roux, J.H., } \\
\text { 'Abraham's rei } \\
\text { and life's mear } \\
\text { et Ecclesia } 36 \text { ( } \\
7 \text { pages. http:/ } \\
\text { org/10.4102/ }\end{array}$ & $\begin{array}{l}\text { is article: } \\
2015 \text {, } \\
\text { interpretation } \\
\text { ning', Verbum } \\
\text { 3), Art. \#1452, } \\
\text { //dx.doi. } \\
\text { /e.v36i3.1452 }\end{array}$ \\
\hline $\begin{array}{l}\text { Note: } \\
\text { This article rep } \\
\text { a theological } r \\
\text { on the Faculty } \\
\text { Theme (FRT) o } \\
\text { of Theology, U } \\
\text { Pretoria, entit } \\
\text { Life in its fulln } \\
\text { theme is portr } \\
\text { the perspectiv } \\
\text { theological dis } \\
\text { conference on } \\
\text { was held on } 2 \\
2014 \text {. }\end{array}$ & $\begin{array}{l}\text { oresents } \\
\text { eflection } \\
\text { Research } \\
\text { f the Faculty } \\
\text { Iniversity of } \\
\text { led 'Ecodomy - } \\
\text { ess'. The } \\
\text { ayed from } \\
\text { e of various } \\
\text { ciplines. A } \\
\text { this theme } \\
7-28 \text { October }\end{array}$ \\
\hline $\begin{array}{l}\text { Copyright: } \\
\text { C 2015. The A } \\
\text { Licensee: AOS } \\
\text { OpenJournals. } \\
\text { licensed unde } \\
\text { Commons Attr } \\
\text { License. }\end{array}$ & $\begin{array}{l}\text { Authors. } \\
\text { IS } \\
\text { This work is } \\
r \text { the Creative } \\
\text { ribution }\end{array}$ \\
\hline Read online: & \\
\hline 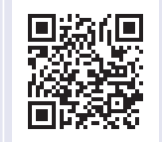 & $\begin{array}{l}\text { Scan this QR } \\
\text { code with your } \\
\text { smart phone or } \\
\text { mobile device } \\
\text { to read online. }\end{array}$ \\
\hline
\end{tabular}

This article contributes to the theme of life's fullness by emphasising the struggle for meaning during the Persian era as reflected in Genesis 15 and 17. The community's 'strategy' was to reflect on their identity in order to find their place in the Persian-ruled society and experience something of life's meaning. Different answers were given and each must be understood separately. In order to survive, one group opted for a broader view of the community and God (Genesis 17), while others were of the opinion that a narrower view had to be followed (Genesis 15). The arguments of both groups are discussed in this article.

\section{The search for life's meaning}

The fullness of life is not a given, but rather a quest - an eternal quest. Fullness, like the meaning of life, will always evade us. It has to do with our finiteness, our inability to control life, our powerlessness in the face of life's tribulations, and our incompetence to fully comprehend life's enigmas or to explain them. However, meaning is experienced when we resist life's absurdities and refuse to be destroyed by them. Revolt is important in this regard (Camus 1955, 1965). This holds true not only against political realities, but also against life's tragedies and misfortunes, because through this resistance one understands the value of one's own existence (cf. Camus 1965). This is another way of experiencing life's fullness.

Meaning and fullness thus implies a creative engagement with life's challenges and the rethinking of one's place in the world. To illustrate this, this article highlights how a community in the province of Jehud during the Persian era attempted to find some meaning in their bleak existence by reflecting on their identity. Although sparse mention is made in the Old Testament of Persia and the Persian king, it was nevertheless a clear and present reality (Hagendorn 2011). Persia formed an 'absent presence', which forced the post-exilic community to rethink their place in the great Persian Empire. In order to survive, this community had to create a new way of thinking about themselves and the world they were living in. They had to change their attitude towards the surrounding nations and this was a rather tough problem to come to grips with (Becking 2011).

It was not an easy road and glimpses of this struggle can still be caught in the way the Jehud community negotiated their identity in Genesis 15 and 17. The kernel of all the arguments was the question about identity. They grappled with the problem of who they were and how to understand their relationship to the other nations. A discussion on their way of finding some meaning in a world where life's fullness often escaped them follows.

\section{Two voices, two perspectives}

In this article we endeavour to understand something of the lifeworld in which these two chapters from Genesis were shaped and moulded. The Pentateuch 'in its current form represents a compromise due to long and difficult negotiations among different religious parties in Jerusalem', and the views found in Genesis 15 and 17 were probably part of this negotiation process (Römer \& Brettler 2000:408-409). If this is so, these chapters should rather stand at the end of these discussions and not at the beginning (Köckert 2013:47).

To discern the distinct voices of both, chapters Genesis 15 and 17 will not be harmonised, but the differences will rather be highlighted. This will enable us to understand something of the individuality and particularity of these texts and their time. What we are looking for can also be explained by means of Michel Foucault's notion of an 'episteme' (Foucault 2009:ix-xxvi). It is a 'code of knowledge' - a kind of intellectual underground, which provided the terms, words and perspectives that the Priestly writer of Genesis 17 and the author(s) of Genesis 15 used to express their views during the Persian era. The 'episteme' can also be described as a kind of 'hidden archive' into which these authors tapped unconsciously to address the problems of their times. If we want to understand the past, we have to grasp the 'episteme' of each era (Kearney 
1989:286). Below, we endeavour to understand the 'episteme' underlying the theological thinking of Genesis 15 and 17, and therefore the differences between the two are stressed.

\section{Living with discontinuities}

One way of understanding the Persian Israel is to use the concepts of 'continuity' and 'discontinuity' (Blenkinsopp 2011). The Persian period was not a continuation of the pre586 era. Scholars tend to describe the exile as a brief period after which things returned to normal. Ezra and Nehemiah confirmed this idealistic view when Ezra stated that the returnees went back to their hometowns:

The priests, the Levites, and some of the people settled in Jerusalem; the singers, the gatekeepers and the temple slaves in their appropriate towns; and all the other Israelites in their own towns. (Ezr 2:70)

This seems 'rather like returning home after a holiday abroad' (Blenkinsopp 2011:463). If we take the harsh realities during the Persian era into account, such a view is rather unrealistic. The returnees had to come to terms with all kinds of discontinuities and they had to struggle to find meaning in this new context.

The events of $586 \mathrm{BC}$ radically changed the Israelite society and its thinking. The Babylonians destroyed the temple, which provided religious legitimacy for the society's existence; the Davidic dynasty was eliminated and there would never be a king again; Jerusalem's fall led to the decline of prophecy and later generations even became critical about prophecy. The Second Temple, which was completed in 515 BC, was a far cry from the one that Solomon built, and it furthermore became 'an instrument of imperial control' (Blenkinsopp 2011:463). In the pre-exilic temple, people prayed for the Davidic kings, but this too changed radically. According to Ezra, king Darius of Persia supported the building of the Second Temple 'so that they may offer sacrifices acceptable to the God of heaven and pray for the life of the king and his sons' (Ezr 6:10). Prayers and sacrifices now had to be made for the family in Susa, the Persian government, the king and his sons (Blenkinsopp 2011:463).

For the Jehud community, many things had changed and it was no mean task to orient themselves in this different world. Hagendorn (2011:48) quotes Lester Grabbe, who once described the Persian period 'as a day of small things' and 'its accomplishments ... not of might nor power but of the spirit' - this can also be seen in all the efforts to answer a question about identity. Genesis 17 provides us with one answer: God is great and other nations can also share in his blessings. In Genesis 15 the perspective becomes narrower, because Yahweh is a God of Abraham's descendants only.

\section{The answer of the priests (Genesis 17)}

The context of Genesis 17 is that of the great, pluralistic Persian Empire and that of the Second Temple, which made Jerusalem the centre of Israel's universe. To understand something of the traces in Genesis 17 about a community who struggled with religious issues, it is our underlying assumption that this chapter deals with two cities that are not mentioned, but which might have functioned in the mind of the Priestly writer (Otto 1997). ${ }^{1}$ The first was Jerusalem, who belonged to the satrapy of Babylonia and the Trans-Euphrate during the early Persian period. During the reign of Darius I Hystaspes (522-486), the empire was reorganised and the province of Jehud or Judah became part of the smaller fifth satrapy called Trans-Euphrates, which was administrated from Damascus. Jehud's territory was rather small and comprised a few kilometres around its centre, Jerusalem (Frevel 2008:673-678).

The other city that functioned in the background of the Genesis 17 narrative was Hebron. This was the place where Abraham had bought land to bury Sarah and where he himself was later buried. Hebron, however, lay outside the region of Jehud, and if someone wanted to visit Abraham's grave, they had to leave Jehud and enter the province of the Idumeans, the Edomites and the Arabs, 'who may have claimed Ishmaelite ancestry' (De Pury 2000:163). It is also possible that the grave had by that time already been built into a shrine and was maintained by the Idumeans. In all likelihood, the Jerusalem community did not judge Hebron favourably. Jerusalem was the place where the Second Temple was built, where the Zadokites functioned as the legitimate priests and the only place where Yahweh had to be worshiped. According to this understanding, Hebron was situated outside Jehud and Jerusalem, and was therefore a place not to be visited. Perhaps this even caused some tension among the members of the Jerusalem community, because they struggled with the notion that another sanctuary could exist outside Jerusalem and Jehud (Schaper 2011).

In Genesis 17 the Priestly writer addressed this problem by reinterpreting the figure of Abraham in such a way as to show that he (the Priestly writer) had no qualms about a shrine in Hebron (De Pury 2000:177). To illustrate his point, the Priestly writer emphasised that Abraham had two sons with two different women: Ishmael, the eldest by Hagar the Egyptian handmaid, and Isaac, the son of Sarah. P then told the story of Abraham's two sons in such a way that both had their place within the Abraham narrative, and Genesis 17 reflects this broader view of the Priestly writer (Ben Zvi 2013). There is openness towards other nations and, according to the Priestly writer, this can already be seen in the early era of the patriarchs. Already in the earliest times of Israel's history, Abraham was a figure of integration - integrating many and different people. In this early stage, Yahweh already made a covenant with Abraham, including also other nations who would share in Yahweh's blessings (Ziemer 2013).

1.According to Anke Mühling (2011:34-35) there is some minimum agreement regarding P: 'Während momentan viele der lange als sicher geglaubten Grundthesen der Pentateuchforschung neu zur Debatte stehen, lässt sich doch in der Zuordnung bestimmter Abraham-Texte zum priesterschriftlichen Textbestand (P) ein weitgehender "Minimalkonsens" erkennen ... Ungeachtet der unterschiedlichen ein weitgehender "Minimalkonsens" erkennen ... Ungeachtet der unterschiedlichen
Erzähldichte lässt sich so im Bereich der Abraham-Überlieferung ein ursprünglich eigenständiger, kohärenter P-Erzählfaden'. 
Genesis 17 highlights the Priestly author's view of Israel as being part of a network of other nations and a more international world. Although Israel had a particular identity as the people of Yahweh, they nevertheless had this openness towards other nations. Although Israel's 'Heilsgeschichte' shaped their faith, they were nevertheless aware of a world history in which Abraham played an important role: 'Die Weltgeschichte bewegt sich auf Abraham, den Stifter der Beschnittenengemeinde zu, ohne eine grundsätzliche Offenheit für andere Völkerschaften aufzugeben' (Gerstenberger 2005:138). ${ }^{2}$

\section{P's Abraham narrative}

To understand Genesis 17, one must comprehend its place within the Priestly writer's Abraham story. Except for Genesis 17 and 23, $\mathrm{P}^{\prime}$ s Abraham narrative is rather sketchy, providing only such information as is necessary to understand Genesis 17. By means of these short notations, $\mathrm{P}$ created a frame within which Genesis 17 can be understood (cf. Noth 1972:8-19; Von Rad [1960] 1961, 1971; Carr 1996; Zenger 1983:148-151, 1997, 2008; Mühling 2011:35).

This frame begins with an itinerary describing how Terah:

... took his son Abram, his grandson Lot son of Haran, and his daughter in law, the wife of Abram, and made them leave Ur of the Chaldaeans to go to the land of Canaan. But on arrival in Haran they settled there ... then he died at Haran. (Gn 11:31-32)

$P$ just states that 'Abram was seventy-five years old when he left Haran' and that he 'took his wife Sarai, his nephew Lot ... They set off for the land of Canaan, and arrived there' (Gn 12:4b-5). The separation of Abraham and Lot is then described in an unspectacular way. It is just stated that the land was too small and that they separated as a result: 'The land was not sufficient to accommodate them both at once, for they had too many possessions to be able to live together'. Thus, they parted company (Gn 13:6, 11b, 12a). Nothing is mentioned of quarrelling herdsmen. P's description of Ishmael's birth is also extremely brief:

Abram's wife Sarai had borne him no child. Thus, after Abram had lived in the land of Canaan for ten years, Sarai took Hagar her Egyptian slave-girl and gave her to Abram as his wife. Hagar bore Abram a son, and Abram gave his son borne by Hagar the name Ishmael. Abram was eighty-six years old when Hagar bore him Ishmael. (Gn 16:1a, 3, 15-16)

Genesis 17 then followed with a brief reference to the destruction of a city in Genesis 19:29, and a condensed depiction of Isaac's birth:

Sarah conceived and bore Abraham a son in his old age ... Abraham named the son born to him Isaac, the son to whom Sarah had given birth. Abraham circumcised his son Isaac when he was eight days old, as God had commanded him. Abraham was a hundred years old when his son Isaac was born to him. (Gn 21:2,3-5)

\footnotetext{
2.Gerstenberger (2005:138) emphasises the universalistic traits of the covenant: Insofern ist der in Genesis 17 gefeierte Bundesschluss Jahwes mit Abraham nach priesterliche Verständnis ein, nein: der Schritt in die partikulare Existenz nach priesterliche Verständnis ein, nein: der Schritt in die partikulare Existenz
des geistlichen Israel, vollzogen und gelebt in der Epoche des Zweiten Tempel, im universalen, pluralistischen Reich der Perser'.
}

A long section (Gn 23:1-20) then follows describing how land was acquired for Sarah's grave, followed by the notice about Abraham's death and the two sons, Isaac and Ishmael, who buried him:

The number of years Abraham lived was a hundred and seventyfive ... His sons Isaac and Ishmael buried him in the cave of Machpelah facing Mamre, in the field of Ephron the Hittite son of Zohar. This was the field that Abraham had bought from the Hittites, and Abraham and his wife Sarah were buried there. (Gn 25:7-10)

The Priestly writer's Abraham narrative is somewhat fragmentary, but the basics were given in order to understand his answer regarding Hebron and Machpelah over against Jerusalem. Abraham left his father and took his wife, Sarah, and nephew, Lot, and came to Canaan. Sarah was barren and gave her Egyptian slave to Abraham, who bore him a son, Ishmael. Abraham bought land at Machpelah where he and his wife would be buried (see Köckert 1988:166-177).

In Genesis 17, the precarious position of Ishmael is described very carefully. He was not part of what we would call the Abraham-Isaac-Jacob-Israel-line, and was basically an outsider. The Priestly writer, however, then carefully devised a strategy to legitimise both the Abraham-Isaac-line and the Abraham-Ishmael-line. According to this strategy, Abraham became a figure of integration, or an ecumenical figure, integrating many different groups. This strategy also helped the Priestly writer to answer the burning religious questions of his day.

\section{Ishmael, a contentious figure}

Ishmael's presence in Genesis 17 has, however, caused some stir in the history of research. All agree that he forms an integral part of the story, but what he received and whether he was included in Yahweh's covenant with Abraham seem to have plagued many a scholar. A Dutch scholar (Gispen 1979) once aptly summarised the convictions of many scholars:

Ismaël deelt in de aan Abrahams zegen van God ... Maar het verbond met God is voor Isaak ... Ismaëls zegeningen zijn niet zegeningen van het verbond... Het verbond van God is voor Isaak, niet voor Ismaël, ook al krijgt hij het teken van het verbond. (pp. 140, 146)

At the beginning of the previous century, Gunkel also held a similar view. According to him, the Priestly author made a huge mistake when he said that Ishmael was also circumcised. It just emphasised that P was not always consistent (Gunkel 1910:272)

Other scholars have argued that verses $12 \mathrm{~b}$ and $13 \mathrm{a}$ were later inserted into Genesis 17, because it is impossible that $\mathrm{P}$ would have told a story about Ishmael's circumcision. Yet others have suggested that we have to change our view of $\mathrm{P}$ as a scrupulous author who always provided precise information, as Genesis 17 confirms P's inconsistent way of working. The mere suggestion that the Edomites and Ketura's children were included in the covenant with Abraham and 
his offspring, Isaac and Jacob, was an impossibility. It was unthinkable that people outside Yahweh's covenant could participate in the blessings of the covenant, and therefore P's account has to be treated with some scepticism (Schmid 2011:9-17).

Konrad Schmid (2011:18) suggested that we can get out of this impasse if we 'read Genesis 17 as a narrative, paying special attention to its various covenantal statements'. Following this proposal, there is a kind of a development regarding the covenant. Firstly, it is stated in verse 2 that God will make a covenant with Abraham 'and I shall ... make you very numerous'. In verse 4 the same is said: '[Y] ou will become the father of many nations'.

In a second remark (verses 7-8) the covenant is expanded, because mention is now made of 'your descendants after you, generation after generation'. At that stage in the narrative, Ishmael was Abraham's only legitimate descendant and the words 'generation after generation' open the way for the later inclusion of Isaac whose birth is narrated only two chapters later. These offspring would participate in two blessings: the experience of God's closeness ('to be your God and the God of your descendants after you') and they would receive 'the entire land of Canaan'. In verses 9-14 the covenant is yet again broadened with the remark about the circumcision. All males had to be circumcised 'including slaves born within the household or bought from a foreigner not of your descent'. Ishmael and all the males were then circumcised and thus became part of the covenant (Schmid 2011:18-26). The Priestly writer wanted to show that the whole of Abraham's posterity (Ishmael, Isaac and their descendants) would be part of him, and would share in the promises of land and God's presence.

Thus, in order to solve the problem regarding Jerusalem and Hebron, and Ishmael and Isaac, P made Abraham an ecumenical figure. Abraham became a figure of integration: integrating many and diverse groups of people in his body, so to speak. It is therefore stated twice that he will become the father of a 'multitude of nations' (Gn 17:4-5), and that nations and kings will come from him (Gn 17:6).

Up to this moment in Genesis 17, the Priestly writer has put forth a solution regarding Hebron and the Ishmaelites who lived there. According to him, the people of Hebron were part of Abraham, and they could rightly call themselves descendants of Abraham who shared in the blessings of the covenant and were part of God's people. The people of Jehud and Jerusalem thus had to view Hebron and the Ishmaelites differently and as much a part of Abraham as they were themselves (Heither \& Reemts 2005:8). ${ }^{3}$

3.Theresia Heither and Christiana Reemts devoted themselves to the study of the reception of figures from the Bible by the theologians of the early church. In the first volume, they wrote about Abraham that he has played a role in the inter-religion debate between Christians, Jews and Muslims. The existence of an inter-religion debate between Christians, Jews and Muslims. The existence of an 'Abrahamitischen/Abrahamischen Okumene' became very important as a mean of linking the descendants of Christians, Jews and Muslims: 'Als Anfang, in dem Judentum, Christentum und Islam vereint sind, stehen die Patriarchen und vor allem die Gestalt des Abraham seit einige Jahren neu im Zentrum des theologische Interesses. Von Abraham erwartet man sich die Kraft, die Gegensätze zwischen den Religionen zu überbrücken, er ist der Grosse Vermittler in einer Ökumene de monotheistischen Religionen' (Heither \& Reemts 2005:8).

\section{Excluded from something}

This answer would not have satisfied the people of Jerusalem, who were deeply conscious of the difference between them and the Hebronites. The Priestly writer was aware of this and therefore subtly distinguished in Genesis 17 between an Abraham-Hagar-Ishmael-line and an Abraham-Sarah-Isaacline. Both lines were the legitimate offspring of Abraham and both shared in the many blessings. There was, however, also a difference, and to understand that, we must first of all comprehend the Priestly writer's understanding of humanity.

According to $\mathrm{P}$, humankind could be divided into three circles, and the people of each circle knew God by a different name (Von Rad 1957:239-240, 1973). The first and widest circle was comprised of those who descended from Noah. Genesis 9 narrates the covenant with the whole of humanity and the cosmos, and the people of this outer circle called God 'Elohim'. Elohim blessed them, established a covenant with them and made them the custodians of the earth (Schmid 2011:6).

In Genesis 17 we find the second circle, the Abraham circle, which had been narrowed down to Abraham and his sons, Isaac and Ishmael. Although humanity was now reduced to one man and his two sons, it nevertheless emphasised that God's covenant included many more than just the AbrahamSarah-Isaac-line. The people who belonged to this circle called God 'El Shaddai'. He made a covenant with them and blessed them with land and with his divine presence (Westermann 1985:258).

Then there was the inner circle comprising of the priests serving at the temple (in Jerusalem), who were responsible for the pure worship of Yahweh. This innermost circle knew God's special name and worshiped him as Yahweh. Ishmael, however, was denied access to this circle. He was not excluded from Yahweh's covenant with Abraham and shared in all the blessings, but he was just not part of the inner circle. He would also experience the presence of Yahweh, but he or his descendants would never serve at the temple in Jerusalem. Ishmael was not neglected or rejected, and God also increased his numbers: he would become the father of twelve princes, but they would never serve as priests of Yahweh. Ishmael was Abraham's beloved son and God also blessed him, but service at the temple was reserved for the Abraham-Isaac-Jacob-Israel-line (De Pury 2000:172-173).

In this way the author of Genesis 17 succeeded brilliantly to shed some light on the religious situation of his times and to answer the difficult questions regarding Abraham, Ishmael and Hebron. By creating an ecumenical Abraham, he succeeded in keeping the two lines in balance and legitimising the Abraham-Isaac-line as well as the AbrahamIshmael-line. By means of this reinterpretation, the Priestly writer recognised the Ishmaelites in Hebron as legitimate descendants of Abraham, who had a right to live on their own land and to worship at Abraham's grave. Although Hebron lay outside of Jehud, the Priestly writer had no objection 'to 
a shared shrine, a shared tradition and a shared territory' (De Pury 2000:177). According to him, this 'very mixture ... is the fulfilment of God's covenant with Abraham' (De Pury 2000:177).

\section{The answer of a prophet}

While Genesis 15 is a reaction to Genesis 17, it lacks the theological broadmindedness of the Priestly writer (Köckert 2013). ${ }^{4}$ The context in which Genesis 15 took shape also struggled with questions about identity and land, which begged for definite answers (Mühling 2011:56). ${ }^{5}$ To formulate an answer, the author(s) of Genesis 15 also reinterpreted Abraham, but in a different way as was done in Genesis 17, and insisted that God's people - the true Israel - consisted only of those who descended from Abraham, who experienced the deliverance from Egypt and who received the promises of the land. In the case of Genesis 15, Abraham became a figure of identification, because the authentic Israel derived from the Abraham-Isaac-Jacob-line and not from the AbrahamIshmael-line (Römer 1989).

To stress this point, the author(s) made Abraham into a prophet (Levin 2013a:216-217). In the Persian era, an ancient figure (Abraham) was thus taken and linked to a phenomenon (prophetism) that only originated much later in Israel's history. A prophet was created who could see the future, as well as the true identity of Israel. Verse 1 therefore clearly states: 'Some time later, the word of Yahweh came to Abram in a vision' (Gn 15:1). The expression 'the word of Yahweh' did not originate with the author(s) of Genesis 15, but came about in prophetic circles where it developed into a typical prophetic formula. The 'word' must be viewed as something with its own power, and in the 'coming of Yahweh's word' lies 'a reference to its eminently historical character and its relation to events' (Levin 2013a:216-217; Zimmerli 1979:144145). The words, 'some time later,' emphasises that the word of Yahweh was not merely a kind of timeless knowledge, but something that was actualised in an historical event or context - something that happened 'some time later' in a specific context and after some events. Put differently, Abraham's prophecy was not a future phantasy, but related to a specific community in a specific time and context.

As in the case of other prophets, Yahweh came to Abraham in a vision (Van Seters 1978:253). This is similar to Amos 3:7, where it is stated that Yahweh made his plans known to his prophet. Like a prophet, Abraham thus 'sees' the future - sees the 'Heilsgeschichte' (Levin 2013b:85-87). Often this type of prophecy is associated with the apocalyptic genre, in which God secretly reveals his plans to a 'prophet' (Ziemer 2005:244-245). There is, however, a huge difference between prophetic eschatology and apocalyptic eschatology.

4.Köckert (2013:43) described the reaction of Genesis 15 to Genesis 17 in a different durch ein Lachen erzetzt haben dürfte, bleibt nur die andere Erklärung, Genesis 15,6 als Korrektur der Reaktion Abrahams in 1,17 zu deuten'.

5.Mühling (2011:56) rightly says that the main themes in the Pentateuch are reflected in Genesis 15 and that 'ist ein deutliches Indiz für die späte, nachpriesterschriftliche Entstehung des Textes'
In prophetic eschatology, God's plans are linked to history, politics and daily life. God's intentions became a reality in the lives of ordinary people. Due to a pessimistic view of the existing social order, apocalyptic eschatology shifted God's acts to a distant future, when all kinds of cosmic events would take place and something new would emerge. The prophet, however, interpreted the existing world as the space where God acts and explained his message in everyday terms. The visionary, on the other hand, was deeply disillusioned and found it nearly impossible to relate God's words and acts to the here and now. He utilised the mode of expression of apocalyptic eschatology to describe God's cosmic acts in future (Hanson 1979:11).

Abraham's prophecy, however, was related to the here and now. The author(s) of Genesis 15 addressed the burning issues concerning identity with which the post-exilic community grappled. Put differently, during the Persian era this community endeavoured to give meaning to their life by means of their reinterpretation of Abraham as a prophet and his 'prophecy' of a 'fourth generation', who would enter the promised land and return to their homeland. In this 'prophecy', mention is made of a future generation: 'Know this for certain, that your descendants will be exiles in a land not their own, and be enslaved and oppressed for four hundred years' (Gn 15:13). The 'prophecy' thus begins with misfortune: Abraham's people will leave the land and will be oppressed and ill-treated, and it will last for 400 years. The third generation, however, will eventually 'leave, with many possessions' (Gn 15:14b). At a certain stage, this generation will escape all miseries, because God will bring them out of Egypt - as Abraham who escaped from Egypt with 'flocks, oxen, donkeys, men and women slaves, she-donkeys and camels' (Gn 12:16), so will the third generation also leave the land of oppression with lots of wealth. There was also a fourth generation, and of this generation it is said that they 'will come back here' (Gn 15:16). Then there was the first generation, which was that of Abraham himself: 'For your part, you will join your ancestors in peace; you will be buried at a happy old age' (Gn 15:15). Abraham's quality of life and death reaches out to his descendants who will one day (through him) share in the good life (Ziemer 2005:204-216).

Important is the promise to the fourth generation that they will return to their homeland. Also, 'prophet Abraham' saw the greatness of the land to which his descendants would return. In verse 18 the land is being described in geographical terms: it stretched from the river of Egypt to the great river, the Euphrates. In verses 19-21 the borders are, however, described in terms of nations: 10 nations are mentioned, not six as in other cases, emphasising once again the vastness of the land. In verse 18 the borders of Israel stretched over a vast area, and it is the widest area ever inhabited by them. In verses 19-21 the land is limited to Palestine, and the different names describe the southern and northern borders of Palestine. These borders do not resemble the ancient borders of an 'Abraham era', but reflect the names of the time of narration during the Persian era of the author(s) responsible for these verses (Köckert 2013:40-41). 
The promise of land to Abraham's descendants was based on a solemn oath, a 'berith'. The presence of God in a smoking oven and the burning torch in verse 17 reminds one of the fire at Sinai. There is, however, also a difference. At Sinai the people looked on from a distance and became involved when they obligated themselves to follow the commandments. In Genesis 15, Yahweh was much more involved, because he himself passed through the animal pieces, thus assuring Abraham that if he (Yahweh) failed his promise he (Yahweh) could also be cut into pieces, just like the animals. The aim of this ceremony was to confirm the words of Yahweh when he said: 'To your descendants I give this land' (Levin 2013b:100, 102). ${ }^{6}$

The notion of the true Israel as those who experienced the exodus events and inherited the promised land, was strengthened by the subtle references in Genesis 15 to Sinai and Moses. To understand this point, we refer to Galling's view of 1928, namely that the patriarchal and exodus narratives were two separate 'Erwählungstraditionen'. These two traditions did not originally follow each other in the same sequence as we now have them. This was only accomplished at a later date (see Albertz 1992:419-427, 2001:191-231; Alt 1966; Noth 1972:45-62).

\section{Abraham and Moses}

According to Konrad Schmid (1999:273-301), the patriarchal narratives and the Moses-exodus-narratives were initially two separate foundation traditions, which were in competition with each other. The patriarchal tradition and the Mosesexodus-tradition initially both functioned separately - both described Israel's beginnings in different ways and each had its own theological focus (Schmid 1999:79-129). In Genesis 15, however, these two foundation stories (of the patriarchs and the Moses- exodus-tradition) were joined together. In order to combine these two foundation stories, the author(s) used 'literary clamps'. Examples of such clamps are the conclusion of Genesis 50, the beginning of the book of Exodus (Ex 1:1-8), Genesis 15, Exodus 3 and Joshua 24. These sections function 'als Klammern zwischen Erzväter- und Moses-ExodusGeschichte' (Schmid 1999:172). Genesis 15 was such a clamp, because the patriarchal and exodus traditions were linked in the text. This link highlights the nature of the true Israel as those who descended from Abraham and experienced the exodus event.

The clamp holding patriarchs and exodus together in Genesis 15 is made stronger by the link that is forged with events at Sinai. The presence of God in a smoking oven and the burning torch (Gn 15:17) calls to mind the smoking oven at Sinai. The darkness (Gn 15:17) reminds one of the darkness at the meeting of Moses with God (Ex 20:21). According to Genesis 15, Abraham thus experienced a theophany long before the Sinai event, though similar to it, and what he received was

6.Levin (2013b:100, 102) states it beautifully: "Gott selbst unterwirft sich dem Fluch um die Verheissung unverbrüchlich zu machen. Stärker kan eine Heilsgarantie nich ausgedrückt werden ... Eine tiefere Selbsterniederung Gottes ist im Alten Testament nirgends erzählt worden'. not inferior to Moses or of a lesser quality to what Moses received at Sinai. There was thus a group (non-priestly) in the Persian era that cherished the idea of Abraham as an equal to Moses. He stood, so to speak, on the same level as Moses, and in post-exilic times this link with Moses was important for questions pertaining to identity: the true Israel derived from Abraham and his descendants who were led out of Egypt, experienced God at Sinai and inherited the promised land (Köckert 2013:39-40). ${ }^{7}$

Genesis 15 appealed to Abraham's descendants who lived in the diaspora during the Persian time. To the people in the Persian time it must have been encouraging to read about a generation of Abraham's descendants who had left the land, but had also returned. To the dispersed descendants of Abraham it must have been a source of hope to know that those descendants who lived outside the land may well return some day. The fact that Abraham 'saw' the 'Heilsgeschichte' and the exodus as well as the Sinai events, forged a link with Moses, which encouraged the despairing community in the post-exilic time to come to grips with questions about estrangement and identity. It showed them that the God of Abraham, who led Israel out of Egypt and met them at Sinai, is still present in post-exilic times and that they can still participate in that experience due to their link with Abraham. In short, in Genesis 15 the true Israel of the Persian era must exclusively be sought in the Abraham-Moses-line and those who suffered in Egypt, experienced the exodus and met God at Sinai.

\section{A last word}

In order to understand something of the discussions about descendants and land during the Persian era, we have treated Genesis 15 and 17 as answers to specific questions. These answers would have helped them to find their way in Persian-ruled Jehud. These answers would have contributed to their life's quality.

In order to experience meaning in their readers' lives, both chapters reinterpreted Abraham in such a way as to shed light on the problems with which the post-exilic community grappled. According to Genesis 17, Yahweh's acts were not restricted to Israel, but included 'outsiders' like Ishmael and his descendants. In the process, Abraham became a figure of integration, uniting diverse groups into himself. The author(s) of Genesis 15 restricted Yahweh's acts to Abraham and his descendants, and thus made Abraham a figure of identity. The true Israel was those who derived their identity from the Abraham-Isaac-Jacob-Israel-line and who experienced the events of the exodus and Sinai.

7. Köckert (2013:39-40) rightly states: 'Während der Grundbestand von Genesis 15 mit Abraham dessen Nachfahren in nach-exilischer zeit direkt anspricht reflektieren die V13-16 ausdrücklich das Verhältnis zwischen dem Ahn einst in der erzählten Zeit und V13-16 ausdrücklich das Verhältnis zwischen dem Ahn einst in der erzählten Zeit und seinen Nachfahren jetz in der Zeit der Erzähler dieser geheimnisvollen Zukunftsschau. Auf diese Weise versuchen jene Erzähler die Spannungen auszugleichen zwischen einem Abraham-Israel, das seit je im Lande war, und einem Exodus-Israel, da von aussen ins Land kommt. Darlei war erst nötig, als beide Konzeptionen in einem Literaturwerk standen. Der Nachtrag hat also programmatischen Charakter und setz eine Pentateucherzählung voraus, welche die Vätergeschichte mit der MoseExodus-Geschichte verbunden hat, mithin nach-priesterlich sein muss'. 
The process of reinterpretation did not stop with Genesis 15 and 17, but was continued in many different ways, with new perspectives being added in the process. However, Anke Mühling aptly said that we must not primarily look for the historical Abraham in these texts, but rather appreciate the way in which he was reinterpreted for the people after the exile, and especially in the diaspora. ${ }^{8}$ Albert de Pury (2000:181) also made an excellent remark when he said: 'even in the final arrangement of the stories, there is something deeply moving in the portrait that is made of Abraham'. This search for the beauty of Abraham and the Old Testament is a never-ending task, which must always inspire the scholar and reader to proceed in life.

\section{Acknowledgements Competing interests}

The author declares that he has no financial or personal relationships that may have inappropriately influenced him in writing this article.

\section{References}

Albertz, R., 1992, Religionsgeschichte Israels in alttestamentlicher Zeit, vol. 1, Vandenhoeck \& Ruprecht, Göttingen.

Albertz, R., 2001, Die Exilszeit: 6. Jahrhundert v. Chr., W. Kohlhammer, Stuttgart.

Alt, A., 1966, 'The God of the fathers', in A. Alt (ed.), Essays on Old Testament history and religion, pp. 101-171, Blackwell, Oxford.

Becking, B., 2011, 'Yehudite identity in Elephantine', in O. Lipschits, G.N. Knoppers \& M. Oeming (eds.), Judah and the Judeans in the Achaemenid period, pp. 403-420, Eisenbrauns, Winona Lake, IN.

Ben Zvi, E., 2013, 'The memory of Abraham in Late Persian/Early Hellenistic Yehud/ Judah', in V.E. Edelman \& E. Ben Zvi (eds.), Remembering biblical figures in the late Persian and the early Hellenistic periods, pp. 3-37, Oxford Press, Oxford.

Blenkinsopp, J., 2011, 'Judaens, Jews, children of Abraham', in O. Lipschits, G.N. Knoppers \& M. Oeming (eds.), Judah and the Judaeans in the Achaemenid period, pp. 461-482, Eisenbrauns, Winona Lake, IN.

Camus, A., 1955, The myth of Sisyphus and other essays, Vintage, New York.

Camus, A., 1965, De mens in opstand, De Bezige Bij, Amsterdam.

Carr, D.M., 1996, Reading the fractures of Genesis, Westminster John Knox, Louisville, KY.

De Pury, A., 2000, 'Abraham: The priestly writer's "ecumenical” ancestor', in S.L. McKenzie \& T. Römer (eds.), Rethinking the foundations: Historiography in the ancient world and the Bible, pp. 163-181, Walter de Gruyter, Berlin.

Foucault, M., 2009, The order of things, Routledge, London.

Frevel, C., 2008, 'Grundriss der Geschichte Israels', in E. Zenger (ed.), Einleitung in das Alte Testament, pp. 587-717, W. Kohlhammer, Stuttgart.

8.Mühling (2011:346-347) stated: "Interessanter ist vielmehr die - historisch nich weniger bedeutsame - Frage, wie die Abraham-Gestalt im Laufe der Zeit literarisch so dargestellt und theologisch so interpretiert wurde dass sie seit dem Exil und (1) dann insbesondere für die in der Diaspora lebenden ... als Identifikationsfigur dienen
Gerstenberger, E.S., 2005, Israel in der Perserzeit, W. Kohlhammer, Stuttgart.

Gispen, W.H., 1979, Genesis, J.H. Kok, Kampen.

Gunkel, H., 1910, Genesis, Vandenhoeck \& Ruprecht, Göttingen.

Hagendorn, A.C., 2011, 'The absent presence: Cultural responses to Persian presence in the Eastern Mediterranean', in O. Lipschits, G.N. Knoppers \& M. Oeming (eds.) Judah and the Judeans in the Achaemenid period, pp. 39-66, Eisenbrauns, Winona Lake, IN.

Hanson, P., 1979, The dawn of apocalyptic, Fortress Press, Philadelphia.

Heither, T. \& Reemts, C., 2005, Biblische Gestalten bei den Kirchenvätern: Abraham, Verlag Aschendorff, Münster.

Kearney, R., 1989, Modern movements in European philosophy, Manchester University Press, Manchester.

Köckert, M., 1988, Vätergott und Väterverheissungen, Vandenhoeck \& Ruprecht, Göttingen.

Köckert, M., 2013, 'Vom "Urgestein" der Väterüberlieferung zum "theologischen Programmtext" der späten Perserzeit', Zeitschrift für die alttestamentliche Wissenschaf 125(1), 25-48. http://dx.doi.org/10.1515/zaw-2013-0003

Levin, C., 2013a, 'Das Wort Jahwes an Jeremia', in C. Levin (ed.), Gesammelte Studien zum Alten Testament, vol. 2, pp. 216-230, Walter De Gruyter, Berlin.

Levin, C., 2013b, 'Jahwe und Abraham im Dialog: Genesis 15', in C. Levin (ed.), Gesammelte Studien zum Alten Testament, vol. 2, pp. 80-102, Walter De Gruyter, Berlin

Mühling, A., 2011, Blickt auf Abraham, euren Vater, Vandenhoeck \& Ruprecht, Göttingen.

Noth, M., 1972, A history of pentateuchal traditions, Prentice Hall, Englewood Cliffs, NJ.

Otto, E., 1997, 'Forschungen zu Priesterschrift', Theologische Rundschau 62, 1-50.

Römer, T., 1989, 'Genesis 15 und Genesis 17', DBAT 26, 32-49.

Römer, T. \& Brettler, M.Z., 2000, 'Deuteronomy 34 and the case for a Persian Hexateuch', Journal of Biblical Literature 119(3), 401-419. http://dx.doi. org/10.2307/3268406

Schaper, J., 2011, 'Torah and identity in the Persian Period', in O. Lipschits, G.N. Knoppers \& M. Oeming (eds.), Judah and the Judeans in the Achaemenid period, pp. 27-38, Eisenbrauns, Winona Lake, IN.

Schmid, K., 1999, Erzväter und Exodus, Neukirchener Verlag, Neukirchen-Vluyn.

Schmid, K., 2011, 'Judean identity and ecumenicity', in O. Lipschits, G.N. Knoppers \& M. Oeming (eds.), Judah and the Judeans in the Achaemenid period, pp. 3-25, Eisenbrauns, Winona Lake, IN.

Van Seters, J., 1978, Abraham in history and tradition, Yale University Press, New Haven.

Von Rad, G., 1957, Theologie des Alten Testament, vol. 1, Chr Kaiser Verlag, München.

Von Rad, G., [1960]1961, 'History and the patriarchs', Expository Times 72, 213-216. http://dx.doi.org/10.1177/001452466107200707

Von Rad, G., 1971, 'Das formgeschichtliche Problem des Hexateuch', in G. von Rad (ed.), Gesammelte Studien zum Alten Testament, TB 8, pp. 9-86, Chr. Kaiser, München.

Von Rad, G., 1973, 'Die Theologie der Priesterschrift', in G. von Rad (ed.), Gesammelte Studien zum Alten Testament, TB 48, pp. 165-188, Chr. Kaiser, München.

Westermann, C., 1985, Genesis 12-36, Augsburg Publishing House, Minneapolis.

Zenger, E., 1983, Gottes Bogen in den Wolken, Verlag Katholisches Bibelwerk, Stuttgart.

Zenger, E., 1997, 'Priesterschrift', Theologische Realenzyklopädie 27, 435-446.

Zenger, E., 2008, 'Die Bücher der Tora/des Pentateuch', in E. Zenger (ed.), Einleitung in das Alte Testament, pp. 156-175, W. Kohlhammer, Stuttgart.

Ziemer, B., 2005, Abram-Abraham, Walter de Gruyter, Berlin.

Ziemer, B., 2013, 'Die aktuelle Diskussion zur Redaktionsgeschichte des Pentateuch und die empirische Evidenz nach Qumran', Zeitschrift für die alttestamentliche Wissenschaf 125(3), 386-388. http://dx.doi.org/10.1515/zaw-2013-0023

Zimmerli, W., 1979, Ezekiel, vol. 1, Fortress Press, Philadelphia. 